\title{
消費電力低減を考慮した高速エレベーター用 アクティブ制振装置の開発*
}

\author{
宇都宮 健 児*1, 岡 本 健 一*1 \\ 湯 村 敬*1, 佐久間 洋 - *2 \\ Vibration Control of High-speed Elevators Taking Account of \\ Electricity Consumption Reduction \\ Kenji UTSUNOMIYA*3, Kenichi OKAMOTO, \\ Takashi YUMURA and Yoichi SAKUMA \\ ${ }^{* 3}$ Mitsubishi Electric Corporation Advanced Technology R \& D Center. \\ 8-1-1 Tsukaguchi-Honmachi. Amagasaki-shi, Hyogo, 661-8661 Japan
}

We have developed an active roller guide system to suppress the lateral vibration of high-speed elevators. Lateral vibration is mainly caused by guide rail deformation and guide rail alignment error. We proved that the active roller guide system is theoretically better than other active vibration isolation methods from a point of electric consumption view. We have developed an original digital-filtering algorithm that enables to avoid waste of electric power due to low frequency noise of accelerometers. These optimum designs enable the development of low electricity consumption system. We manufactured an active roller guide and conducted experiments with actual elevators in experimental towers. Experimental results show that the active roller guide system is capable of reducing the lateral vibration of elevator cars to nearly half with low power consumption.

Key Words: Elevator, Vibration Control, Electricity Consumption. Filter. Electromagnetic Actuator

\section{1. 粕}

エレベーターの乗り心地指標の一つとして, かご 横振動がある. かご横振動は，昇降路内に設置される ガイドレールの曲がりや継ぎ目部据付誤差により，か ごが強制加振されて生じる. 現在の高速エレベーター では，かごの上下左右 4 箅所に設けられるローラーガ イドのばね剛性と減衰を適正に調整することで横振動 を低減している. しかし，エレベーターが高速化する と，このような剛性・減衰の最適化だけでは横振動を 抑えることが難しくなるため, 振動源であるレ一ル曲 がりを加工時と据付時に厳しく管理することで良好な 横振動性能を達成している. しかしこの方法は非常に 高レベルの加工・据付技術を要するため, 据付熟練者 の不足する海外で国内と同等な性能を維持することが 難しいといつた問題がある. また, レ一ルの経年変化 により乗り心地が悪化するといった問題もある.

このような背景からエレベーターの横振動を低減 する新技術への二ーズは大きく，これまでにも多く の手法が検討されている. 特に，かご振動をセンサ で検出し，外部からかごに力を付加して振動を低減

* 原稿受付 2006 年 2 月 2 日

*1 正員, 三菱電機 (株) 先端技術総合研究所( $\mathbf{W} 6618661$ 尼崎 市塚口本町 8-1-1)

*2 正員, 三菱電機 (株) 稻沢製作所.

E-mail : Utsunomiya.Kenji (a db.MitsubishiElectric.co.jp
するアクティブ制振技術が振動低減に有効な方法と して注目されており，かご下部に設けたボールねじ とモー夕によりかご振動を低減する手法(1) (3)や， ガイド部に設けた電磁石の吸引力によりかご振動を 低減する手法 ${ }^{(4)}$ や，アクティブマスダンパを用いた 手法(5) (9)などが検討されている. 一方, 工業的に 広く使用するためには, 既存のエレベーター設備仕 様を変更せずに設置可能でなければならないという 課題がある. そのためには，消費電力を抑え電源設 備の負担を減らすとともに, 他機器との干涉防止の 観点から小型であることが必要となる．そこで本報 では, 必要エネルギ一の最小化に着目したアクティ ブ制振技術開発結果について示す。

\section{2. 基本構成}

21 エレベーターの構成 乗り場正面から見た エレベーターかご断面モデルを図 2.1 に示す. 昇降路 内のガイドレールに沿って，かご枠に取り付けられた ローラーガイドが案内されることで昇降を繰り返す。 かごは，ローラ支持ばね，振れ止めゴム，防振ゴムで 支持されている. この支持機構は, レールから伝わる 振動を緩和する防振機構としての役割と，レールに対 するかご傾きを抑える支持機構としての役割を有し， 両者のトレードオフで剛性が決められている，本章で は定性的な検討を行うため，図 2.1 に示すモデルを簡 
易化した図 2.2 の 2 慣性モデルを用いる（簡単のため 減衰は無視した）。高速エレベーターの代表的な值を 表 2.1 に示す．また本論で指す高速エレベーターは, 定格昇降速度が $5 \sim 10 \mathrm{mms}$ の間のものを指す.

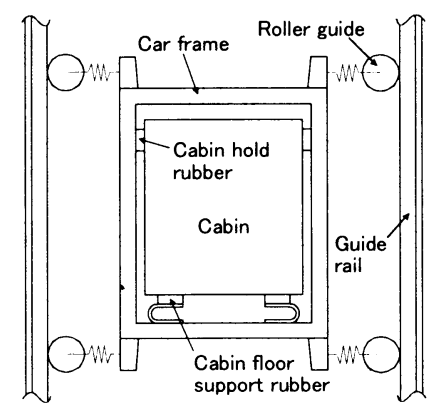

Fig2.1 Elevator model

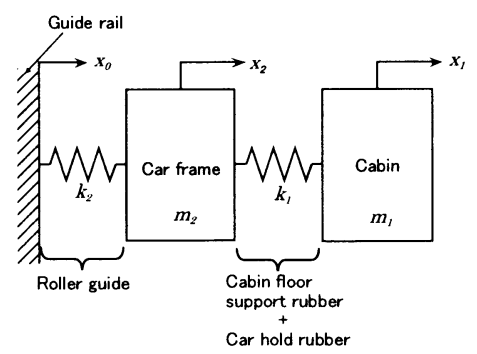

Fig2.2 2DOF model

アクティブ制御の考え方の一つとして, 制御対象の特 性をアクティブ制御しやすいように再設計する制御器 と制御対象の同時設計がある(10). しかし，かごの剛 性パラメータはエレベーターに設置された各種安全装 置の設定や荷重条件の兼称合いで最適に決定されてい るため, 仮に制御が停止した場合にもフェイルセーフ な構成となるように, かごのパラメー夕は変更しない，

Table2.1 Parameters of 2DOF model

\begin{tabular}{|l|l|}
\hline $\mathrm{m}_{1}:$ Mass of cabin & $2300[\mathrm{~kg}]$ \\
\hline $\mathrm{m}_{2}:$ Mass of frame & $3500[\mathrm{~kg}]$ \\
\hline $\mathrm{k}_{1}:$ Stiffness of rubber & $1.8 \mathrm{e} 7[\mathrm{~N} / \mathrm{m}]$ \\
\hline $\mathrm{k}_{2}:$ Stiffness of guide spring & $5.9 \mathrm{e} 5[\mathrm{~N} / \mathrm{m}]$ \\
\hline
\end{tabular}

2.2 レール外乱特性 最適な制御方法を検討 する場合に，制御対象の特性と合わせて重要になる のが外乱特性であり, 通常の高速エレベーターで振 動要因となるのはガイドレールの曲がりや据付誤差 である(11). 代表的なものを表 2.2 に示す.

(1) レール1本の一次曲り

ガイドレール 1 本の加工誤差に起因するもので, おおよそレール 1 本分が 1 周期の正弦波で近似され
る. レール 1 本分の長さ $l_{r}$ は $4 \sim 5[\mathrm{~m}]$ が代表的な値 であるから, 昇降速度 $v_{h}$ の範囲が $5 \sim 10[\mathrm{~m} / \mathrm{s}]$ とする と, その加振周波数 $f$ ，は式(2.1)のようになる.

$$
f_{r}=v_{h} / l_{r}=1.0 \sim 2.5[\mathrm{~Hz}]
$$

(2) <の字曲がり

ガイドレール継ぎ目部端面の加工誤差や据付誤差 に起因するくの字形状の曲がりで三角波で近似され る. レール 2 本で 1 周期となるため, 基本加振周波 数 $f_{r}$ は式(2.2)のようになる.

$$
f_{r}=v_{h} / 2 l_{r}=0.5 \sim 1.25[\mathrm{~Hz}]
$$

(3) 段差

レール継ぎ目部の据付誤差に起因するステップ状の 外乱である. 高速エレベーターでは，ローラ表面のゴ ムで吸収されほとんど問題になることがない.

Table 2.2 Main characteristics of guide rail disturbance

\begin{tabular}{|c|c|c|c|}
\hline Name & Bending & Skew at joint & Level difference \\
\hline & &
\end{tabular}

23 アクティフ制御方式別性能検討 制御方 式として以下の 4 種類を考える. 制御の安定性を考 慮し, センサとアクチュエータの配置がコロケート な方式で検討した.

（1） かごの状態を観測して，かご・かご枠間に 取り付けたアクチュエータで制御する方式. （以下，かご·かご枠間方式, Case1）

（2） かご枠の状態を観測して，ガイド部に取り 付けたアクチュエータで制御する方式. (以下，ガイド方式，Case2)

（3） かごの状態を観測して, かごに取り付けた アクティブマスダンパで制御する方式.

(以下, かごマスダンパ方式, Case3)

（4） かご枠の状態を観測して, かご枠に取り付 けたアクティブマスダンパで制御する方式. (以下, かご枠マスダンパ方式, Case4)

また，制御目標及び制約として以下を考える. （A）乗り心地の改善（1次モードの制振性能） 
レール外乱の主成分周波数は $0.5 \sim 2.5 \mathrm{~Hz}$ である. この周波数帯域にある 1 次振動モードの低減が主目 的となる. 評価量は, レール変位外乱 $\mathrm{x}_{0}$ からかご 変位 $\mathrm{x}_{1}$ までの伝達特性（図 2.3）の1次モードピー クとする.

（B）制御エネルギーの低減

本論の主命題である制御エネルギ一の低減. 特に 外乱の主成分が存在する低周波域でのエネルギ一低 減を実現するため, 評価量は外乱 $\rightarrow$ 制御力伝達特性 （図 2.4）の低周波ゲイン值とする.

（C）偏荷重に対するロバスト性

エレベーターでは, 乗客荷重の不均一性や, ケー ブル等の周辺機器重量に起因して傾きが生じる. 通 常アクティブ制振の振動検出には加速度センサを用 いるが, 偏荷重による傾きは加速度センサに重力加 速度に起因した大きな低周波外乱を発生させ, 無駄 なエネルギー消費やアクチュエータのストロークオ 一バーの原因となる. エネルギ一評価量は（B）と 同じとし，ストローク評価量は外乱 $\rightarrow$ スローク伝 達特性（図 2.5）を考える. 1次モ一ド周波数が比 較的低いため, ハイパスフィル夕等による大幅な低 周波ノイズ除去は難しいと考え，伝達特性の低周波 域での傾きが正であることをストロークオーバ防止 の仕様とする.

（D）巻上機負荷の軽減（装置重量の制約）

制振装置の重量増大は巻上機負荷増の原因となり, 大きくなると本論の趣旨に対して本末転倒となる. 方式 3〜 4のマスダンパ方式は付加マス重量が大き いほど有利であるが，一般に付加マスの質量比が主 系の数\%程度であることを考慮し $100 \mathrm{~kg}$ とした.

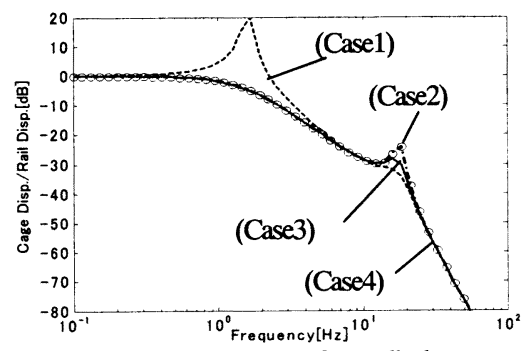

Fig 2.3 Frequency response of cage displacement

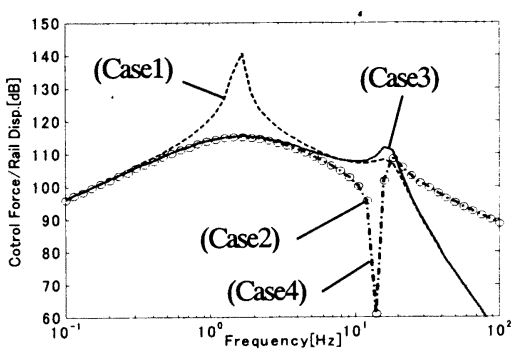

Fig 2.4 Frequency response of control force

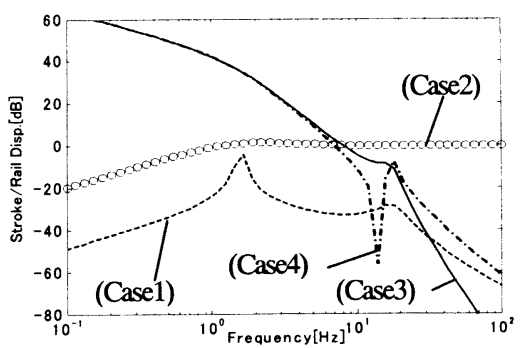

Fig 2.5 Frequency response of actuator stroke

Table 2.3 Comparison of performance

\begin{tabular}{|c|c|c|c|c|c|}
\hline & Structure & Equation & (A)Efficiency & (B)Fonce & (C)Stroke \\
\hline 1 & $\underset{m_{2}}{\mathrm{~m}_{1}}$ & $\begin{array}{l}m_{1} \ddot{x}_{1}+k_{1}\left(x_{1}-x_{2}\right)=K_{p} \dot{x}_{1} \\
m_{2} \ddot{x}_{2}-k_{1}\left(x_{1}-x_{2}\right)+k_{2}\left(x_{2}-x_{0}\right)=-K_{p} \dot{x}_{1}\end{array}$ & $\begin{array}{c}\times \\
(20 \mathrm{~dB})\end{array}$ & $\begin{array}{c}\times \\
(140 \mathrm{~dB})\end{array}$ & $\underset{(+20 \mathrm{~dB} / \mathrm{dec})}{\bigcirc}$ \\
\hline 2 & $m_{2}-\mathrm{W}_{k_{1}} m_{1}$ & $\begin{array}{l}m_{1} \ddot{x}_{1}+k_{1}\left(x_{1}-x_{2}\right)=0 \\
m_{2} \ddot{x}_{2}-k_{1}\left(x_{1}-x_{2}\right)+k_{2}\left(x_{2}-x_{0}\right)=K_{p} \dot{x}_{2}\end{array}$ & $\underset{(-5 \mathrm{~dB})}{\bigcirc}$ & $\underset{(115 \mathrm{~dB})}{\bigcirc}$ & ${ }_{(+20 \mathrm{~dB} / \mathrm{dec})}$ \\
\hline 3 & 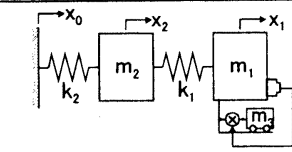 & $\begin{array}{l}m_{1} \ddot{x}_{1}+k_{1}\left(x_{1}-x_{2}\right)=-K_{p} \dot{x}_{1} \\
m_{2} \ddot{x}_{2}-k_{1}\left(x_{1}-x_{2}\right)+k_{2}\left(x_{2}-x_{0}\right)=0 \\
m_{3} \ddot{x}_{3}=K_{p} \dot{x}_{1}\end{array}$ & $\begin{array}{c}0 \\
(-5 \mathrm{~dB})\end{array}$ & $\underset{(115 \mathrm{~dB})}{\bigcirc}$ & $\begin{array}{c}\times \\
(-20 \mathrm{~dB} / \mathrm{dec})\end{array}$ \\
\hline 4 & 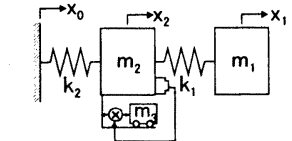 & $\begin{array}{l}m_{1} \ddot{x}_{1}+k_{1}\left(x_{1}-x_{2}\right)=0 \\
m_{2} \ddot{x}_{2}-k_{1}\left(x_{1}-x_{2}\right)+k_{2}\left(x_{2}-x_{0}\right)=-K_{p} \dot{x}_{2} \\
m_{3} \ddot{x}_{3}=K_{p} \dot{x}_{2}\end{array}$ & $\underset{(-5 \mathrm{~dB})}{\mathrm{O}}$ & $\stackrel{\bigcirc}{\bigcirc}$ & $\begin{array}{c}\times \\
(-20 \mathrm{~dB} / \mathrm{dec})\end{array}$ \\
\hline
\end{tabular}


なお本検討では，制振制御への実用例の多いスカ イフック制御（速度フィードバック制御）を制御則 として適用し, そのゲインは $K p=1.0 \times 10^{5}$ に統一し た.（A）〜（C）に示した評価量の伝達特性を図 2.3〜2.5 に示し, 各制御方式の構成図, 運動方程式, 評価結果を表 2.3 に示す。

・ かご·かご枠間方式（Case1）はアクチュエータ 設置位置がモ一ドの節となるため，1次モ一ド の制振効果とエネルギー効率の点で問題がある.

・ガイド方式（Case2）は 1 次モードの制振効果, エネルギ一効率ともに優れ，低周波での制御又 トロークもレール変位外乱と同等以下となる。

・ かごマスダンパ方式（Case3）は理論上完全な スカイフック特性を実現できるため, 1次, 2 次モ一ドともに制振効果に優れ, エネルギー効 率も良い。しかし低周波域における制御ス卜ロ 一ク特性が-40〜-20dB/dec となっており，かご 偏荷重に対するロバスト性の面で問題がある.

・ かご枠マスダンパ方式（Case4）は制振効果と エネルギー効率の点ではガイド方式と同等であ るが，かごマスダンパ方式と同様に制御ストロ 一クの点で問題がある.

以上の考察より, 制御目標である（A）乗り心地, （B）エネルギ一効率，（C）偏荷重へのロバスト性 の全てを満たすガイド方式（Case2）を採用した.

\section{3. アクチュエータの最適化}

3.1 アクチュエータの基本仕様 前章の検討で アクチュエータをかご枠とレールとの間, つまりガイ ド部に設けたほうが, 必要制御力を小さくでさること が分かった. 本章ではガイド部に設置するアクチュエ 一夕構造の消費電力最小化設計を考える.

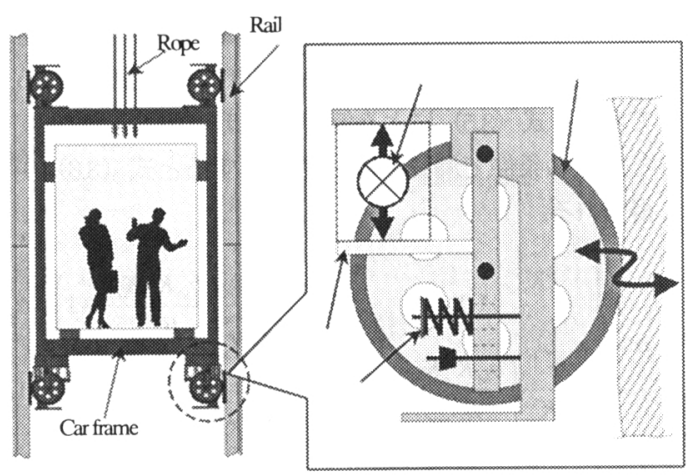

Fig. 3.1 Arrangement of Actuator
ローラーガイドの拡大図を図 3.1 に示す. エレベー タ一の他機器との干渉を考えると, 追加するアクチュ エー夕は図 3.1 の点線部に示すように従来のローラー ガイドの寸法内に入ることが一つの重要な設計仕様と なる．また，寿命，信頼性，メンテナンス性を考虑す ると非接触な構造であることが必要となる.

アクチュエータの駆動方向は上下方向で, アームを 介してローラを摇動することでガイドレールに対し水 平方向の力を伝達するような構成とする.

実際のレール曲がりデー夕を使用した数值シミュレ ーションより, 本構成でのアクチュエータストローク は土2[mm]程度であった．しかし，かご内にかかる偏 荷重による変位分を考虑すると $\pm 10[\mathrm{~mm}]$ のストローク が必要となる.

以上より条件を

・非接触駆動方式であること.

・駆動ストローク $\pm 10[\mathrm{~mm}]$

- 外形寸法は $W H D=100 \times 140 \times 100$ [mm]以内

として, アクチュエータ検討を行う.

32 方式検討 非接触式アクチュエータの代 表例として電磁石とボイスコイルモータ（以下 VCM）がある. そこでまず既定の寸法条件下で， 消費電力最小化の観点から両方式の比較を行う.

Table 3.1 Actuator comparative table

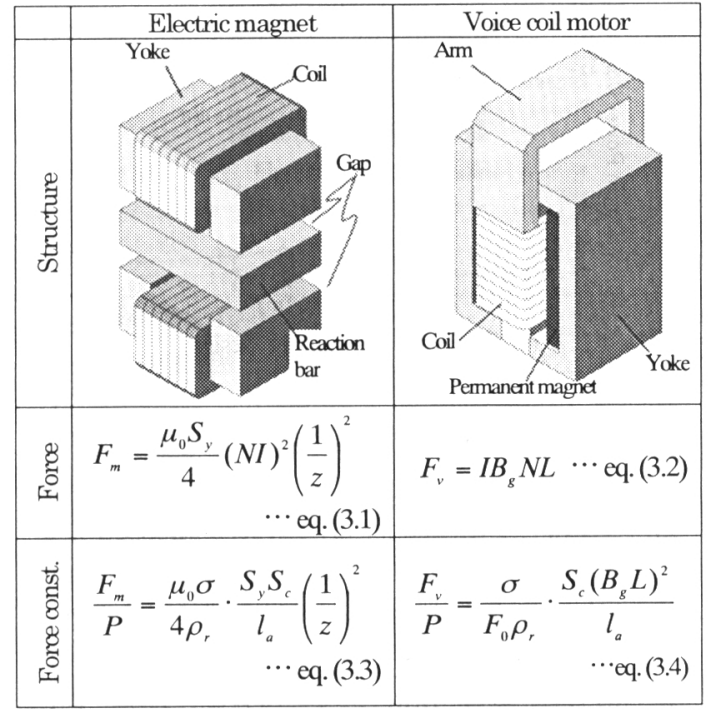

表 3.1 はその比較を示したものであり，上段より， 構成概略図, 発生力の基本式, 基本式から導出される 
一定電力に対する力定数の式である．各記号の意味は 次のとおりである.

$\mu_{0}:$ 空気の透磁率, $N$ : コイルターン数, $I:$ 電流

$S$ : ヨーク断面積, $S:$ :コイル断面積

$z:$ 磁気ギャップ, $B_{g}$ : ギャップ部磁束密度

$L$ : コイル有効長, $l_{a}: 1$ ターン平均コイル長さ

$\sigma$ : 占有率, $\rho_{r}$ : 抵抗定数

必要電力最小化問題は単位電力あたりの力定数, 式(3.3) (3.4)の最大化問題に置き換えられる. 式(3.3)及 び(3.4)の右辺はターン数 Nが消えており, コイル形状 やヨーク形状が一定であれば, 力定数はターン数 $N$ に依存しないことが分かる. つまり力定数の最大化問 題は, 外形寸法条件下でのコイル, ヨーク, 磁石の形 状最適化問題となる.

アクチュエータストロークに対する力定数最適設計 結果を図 32 に示す. 電磁石方式では力定数がストロ 一クの 2 乗に反比例するため, ストロークが短い場合 に有利である. 一方, VCM 方式は力定数がストロー クにほとんど依存しないため, ストロークが長い場合 に有利となる. 図 32 より, ストローク $\pm 10[\mathrm{~mm}]$ の条 件下では，VCMが電磁石と比較して力定数が 6〜 7倍 となっている. 以上より長ストローク条件下でのエネ ルギー効率に優れた VCM方式を選択する.

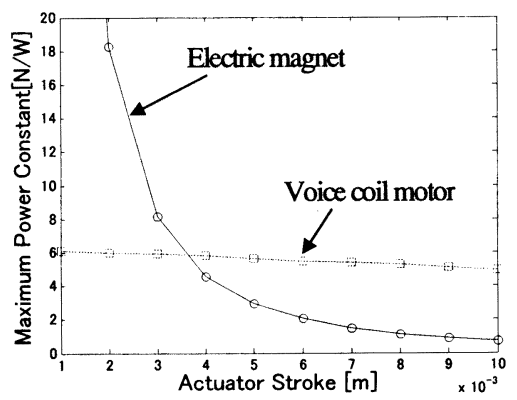

Fig 3.2 Result of Optimum Design

$3.3 \mathrm{VCM}$ の最適設計 $\mathrm{VCM}$ の力定数最適設計 についてもう少し詳細に述べる. 図 3.3 に, 日の字形 ヨークを持つショートコイル式 VCM の概要図を示す. この VCM を規定条件下で, 単位電力量あたりの発生 力が最大となるような最適設計を行う.

表 3.1 に示したように, VCM の発生力 $F_{y}$ は， ロー レンツカとして式（32）のように与えられる. ギャ ップ部の磁束密度 $B_{g}$ はパーミアンス法 ${ }^{(12)}$ などを用 いて計算されることが多い. しかしパーミアンス法に おける漏㖂磁束経路の推定は経験的なものによるとこ
ろが大きく, 最適設計計算に用いるには多少煩雑であ る. そこで，本検討では以下のような仮定を置くこと て磁束の漏れ係数 $\rho$ を推定した.

【磁束漏れに対する仮定】

・ ヨーク材の飽和磁束密度を $B_{\text {max }}=1.6[T]$ とする.

- ヨーク中の磁束密度 $B_{y}$ が $B_{y}$ max 以下時は漏れ係 数は $\rho=1.1$ で固定とする.

・ $B_{y}$ が $B_{\text {max }}$ に達している場合は，磁束漏れはヨー クの磁束飽和にのみ起因すると仮定し他の漏れは 無視する.

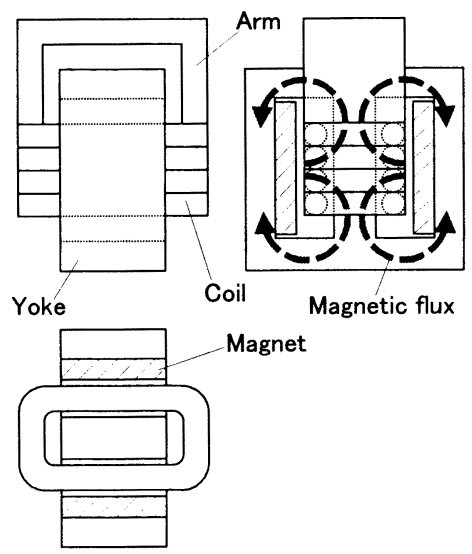

Fig 3.3 Structure of Voice Coil motor

また, 永久磁石の滅磁特性は式（3.5）のように直 線近似できるものとし, 起磁力損失係数 $f$ は 1.2 で固 定であるとした.

$$
H_{m}=-a_{b h} B_{m}+b_{b h}
$$

$H_{\mathrm{m}}$ : 磁石表面での磁界強さ， $B_{\mathrm{m}}$ : 表面磁束密度

なお今回，永久磁石として(株)NEOMAX 製のネオ ジウム系磁石 NEOMAX-46BH の使用を仮定している が，その減磁曲線はパーミアンス係数 $p$ が非常に小さ い場合（ $p$ が 0.1 以下）を除けばほぼ直線特性となっ ており，式（3.5）による仮定はほぼ問題ない.

以上の条件で漏れ係数 $\rho$ を計算すると式（3.6）が 得られる.

$$
\rho=\left\{\begin{array}{cl}
1.1 & \text { if } \frac{1}{a_{b h} K_{p}}\left(\frac{b_{b b} K_{p} K_{b y}}{B_{y \max }}-1\right) \leq 1.1 \\
\frac{1}{a_{b h} K_{p}}\left(\frac{b_{b h} K_{p} K_{b y}}{B_{y \max }}-1\right) & \text { if } \frac{1}{a_{b h} K_{p}}\left(\frac{b_{b h} K_{p} K_{b y}}{B_{y \max }}-1\right)>1.1
\end{array}\right.
$$




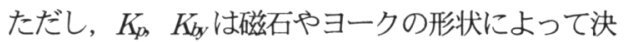
まる变数である. 漏孔係数 $っ か ゙$ 決まると永久磁石の動 作点を示すパーミアンス係数 $p$ の関係式 (3.7) と減 磁特性式（3.5）とから表面磁束密度 $B_{m}$ が決定される.

$$
(p=) \frac{B_{m}}{H_{m}}=\mu_{0} \frac{A_{g}}{l_{s}} \cdot \frac{l_{m}}{A_{m}} \cdot \frac{\rho}{f}
$$

$A_{g}:$ ギャップ部面積, $g_{g}:$ ギャップ長

$A_{m}:$ 磁石面積, $l_{m}:$ 磁石厚さ

さらに磁気回路の基礎式である式（3.8）よりギヤ ップ部の磁束密度 $B g$ が導き出される.

$$
A_{m} B_{m}=\rho A_{g} B_{g}
$$

ここで発生力 $F_{V}$ の式 (3.2) に戻る. VCM の発生 力 $F_{v}$ は電流に比例するため, 力定数 $F_{v} / P[\mathrm{~N} / \mathrm{W}]$ は電流 依存となる. そこで本検討では, $F_{\mathrm{v}}=F_{0}(=100[\mathrm{~N}])$ とな るような電流 $I_{0}$ が生じる場合の力定数 $F_{v} / P[\mathrm{~N} / \mathrm{W}]$ を最 大にすることを設計目的とする. この $F_{0}$ は数值シミ ユレーションによって導き出された, 通常走行時に必 要な最大制御力に近い值である.

ターン数 Nの式 (3.9) とコイル抵抗の式 (3.10) を 式（3.2）に代入し整理すると式（3.4）を得る.

$$
\begin{aligned}
& N=\frac{S_{c} \sigma}{\pi(\phi / 2)^{2}} \\
& R=\rho_{r} \frac{N l_{a}}{\pi(\phi / 2)^{2}} \\
& \phi: \text { コイル線径 }
\end{aligned}
$$

式（3.4）で示した単位電力あたりの力定数を, ス トローク $10[\mathrm{~mm}]$ として計算した結果を図 3.4 に示す. 設計の自由度は 2 となり，ここでは横軸にヨークの厚 さ, 縦軸にコイルの厚さをとっている. 最適点は図中 の×印であり, 最大力定数 $4.9[\mathrm{~N} W]$ 得た.

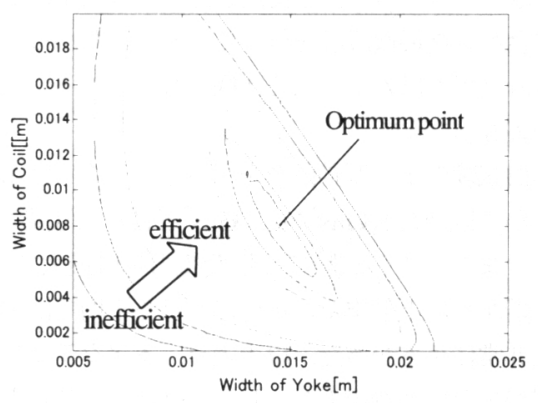

Fig 3.4 Optimum Design of VCM

図 3.4 は以下のように説明される.

・磁束密度 $B_{g}$ はコイル厚さが薄いほど大きくなる が, 逆に有効長 NLは小さくなる. そのトレード オフにより最適点が存在する.

- 図 3.4 中, 左下部分は磁石厚さは厚いが漏孔磁束 が多く効率の悪い領域である. 逆の右上部分は寸 法制限上磁石が薄くなるためパワーが出ない領域 である. 単位電力あたりの力定数（3.4）の極大 領域はこのトレードオフとしてパーミアンス保数 がほぼ1 となる付近に存在する.

アクチュエータのストロークを 1 〜 $10[\mathrm{~mm}]$ の間でふ った場合の最適計算結果を示したものが既出の図 3.2 である.

$3.4 \mathrm{VCM}$ の試作 以上の消費電力の観点から見 た最適計算に基づき高効率な VCM を開発試作した。 ただしコイル線径は $0.6[\mathrm{~mm}]$ で設計している. 写真を 図 3.5 に示す. なお試作数 20 個の平均力定数は 4.99 [NW]で計算結果とほぼ一致しており，最適計算の妥 当性を示している.

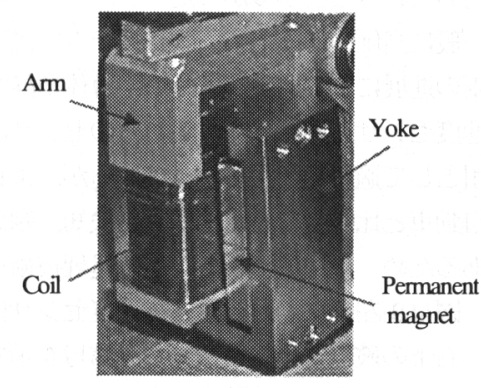

Fig 3.5 Voice coil motor

Table 3.2VCMcharacteristics

\begin{tabular}{|l|l|}
\hline Resistance & $12.3[\Omega]$ \\
\hline Force constant & $4.99[\mathrm{~N} / \mathrm{W}](61.4[\mathrm{~N} / \mathrm{A}])$ \\
\hline Turn of coil & 1013 \\
\hline Diameter of $\infty i l$ & $0.6[\mathrm{~mm}]$ \\
\hline
\end{tabular}

\section{4. 信号処理技術}

4.1 基本制御アルゴリズム基本的な制御則と しては，鉄道や自動車のアクティブ制振装置などに適 用例の多いスカイフックダンパ方式を用いた. 制御基 本ループのブロック線図を図 4.1 に示す.

かご枠に設置された加速度センサで検知された振動 信号はコントローラに送信され, 初段のローパスフィ ルタとハイパスフィルタによって制御しない高周波数 


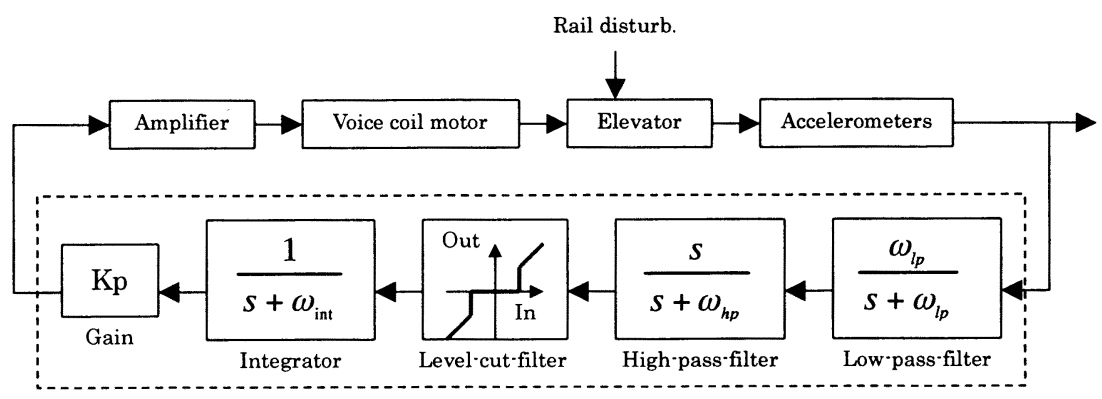

Fig. 4.1 Block diagram of active roller guide

域と低周波数域のノイズを除去される. さらに，無駄 な電力消費を防止するためのレベルカットフィルタ

（詳細は後述する））により微小ノイズをカットされ た後積分される.このようにかご枠の絶対速度に比例 した力を VCM で加えることでスカイフック特性を付 加し, エレベーターかごに加えられるレール変位外乱 に対する感度を小さくしている.

42 レベルカットフィルタ これまで微小振動 （mG レベル）制御用には, 高精度なサーボ式加速度 計が用いられることが多かった. しかしサ一ボ加速度 計は一般に高価であるため, 本システムでは近年半導 体技術の進展により進歩力著しい半導体型静電容量式 の加速度センサを適用した.これらのセンサは自動車 制御用として適用範用が広がっているが，エレベー夕 一は自動車と比較して小さな振動を検知，制御する必 要があるため, 適用には新たな信号処理技術を必要と した. 図 42 左下に静電容量式加速度センサ信号の一 例を，右下の破線でそれを積分した信号を示す．この ようにフィルタによって除去しきれない低周波ノイズ が積分により挔大され大きな信号となって現れている. このような低周波ノイズによる制御指令は，かご静止 時のフワフワ感として乗り心地に悪影響を及ぼすだけ でなく，電力を無駄に消費してしまうため，これを防 止する技術としてレベルカットフィルタを開発, 適用 した.

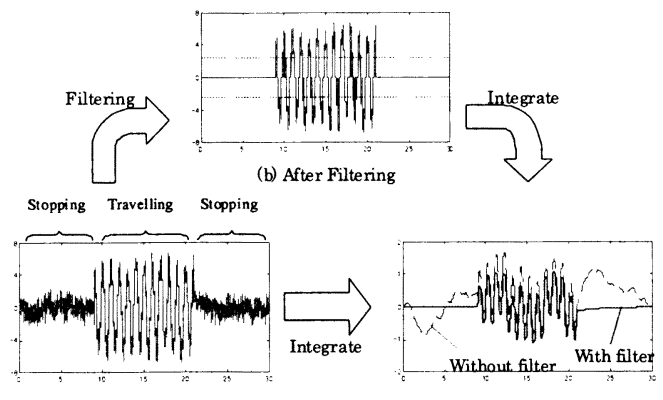

(a) Acceleration Signal
従来の低周波ノイズを低減する方法として, ハイパ スフィルタの次数を上げる, カットオフ周波数を上げ ることが考えられる. しかしかごの 1 次振動モ一ド周 波数が低いため, 位相まわりによる制御の不安定化の 観点から両方法ともに適用は難しい.

一方，レベルカットフィル夕では，加速度信号に対 して一定レベル以下の信号を図 4.2 上段のようにゼロ 出力する. その後に低域力ットを含めた積分を行うと 図 4.2 右下実線のように停止中の信号は必ずゼロに収 束する. このときの低域力ット周波数は非常に低い周 波数で良いため, 制御の安定性には悪影響を及ぼさな いというメリットがある. また, 微小成分のみ除去す るため走行中の信号には大きく影響しない.

このようにレベルカットフィルタと積分後のハイパ スフィル夕を組み合わせることで, 安定性を確保しつ つ, 無䭾な電力消費を防止することを可能とした.

\section{5. 実松試検}

消費電力最小化の観点から実施した検討をもとに, アクティブローラーガイドを試作した. 写真を図 5.1 に示す.

またアクティブ制振装置の性能を確認するため，実 機試験を実施した. ただしこの実機試験では，一回り 大きなローラーガイドを使用したため VCM はその寸 法に合わせた最適設計を行っている. したがって 3 章 の設計結果とは若干異なる仕様となっている. 試験条 件を表 5.1 に示す.

実機試験のかご振動波形を図 5.2 に示す．図 5.2 よ り，かご振動を $23 \mathrm{~cm} / \mathrm{s}^{2}$ から $9 \mathrm{~cm} / \mathrm{s}^{2}$ 亡良好に低减できて いる. また，この試験での消費電力量は最大で $70 \mathrm{~W}$, 最下階から最上階までの走行における平均では $6 \mathrm{~W}$ 程 度と非常に小さかった. 以上より，本アクティブ制振 装置が少ない消費電力で, レール外乱によるかご振動 を効果的に低減できることを実機試験においても確認 することができた.

Fig. 4.2 Effect of level cut filter 
Table 5.1 Specifications of test system

\begin{tabular}{|l|l|}
\hline Elevator & $\begin{array}{l}\text { Velocity : } 420 \mathrm{~m} / \mathrm{min} \\
\text { Capacity }: 1600 \mathrm{~kg}\end{array}$ \\
\hline Voice coil motor & $\begin{array}{l}\text { Force constant }: 75 \mathrm{~N} / \mathrm{A} \quad \mathrm{MAX}: 150 \mathrm{~N}) \\
\text { Coil resistance }: 11.3 \Omega\end{array}$ \\
\hline \multirow{2}{*}{ Amplifier } & $\begin{array}{l}\text { PWM, bi-polar } \\
\text { Maximum input voltage }: \pm 3 \mathrm{~V} \\
\text { Maximum output current }: \pm 2 \mathrm{~A}\end{array}$ \\
\hline \multirow{3}{*}{ Accelerometers } & $\begin{array}{l}\text { Sensitivity }: 50 \mathrm{~V} / 1 \mathrm{G} \\
\text { Frequency region }: 0.1 \mathrm{~Hz} \sim 160 \mathrm{~Hz} \\
\text { Noise level }: 4.5 \mathrm{~cm} / \mathrm{s}^{2}(\mathrm{p}-\mathrm{p})\end{array}$ \\
\hline Controller & $\begin{array}{l}32 \text { bit DSP board }: \mathrm{ADSP} 324-00 \mathrm{~A} \\
\text { Sampling frequency }: 1 \mathrm{kHz}\end{array}$ \\
\hline
\end{tabular}

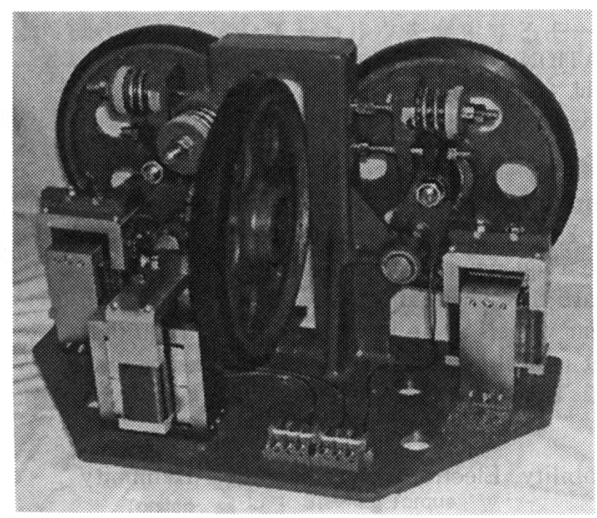

Fig 5.1 Active roller guide

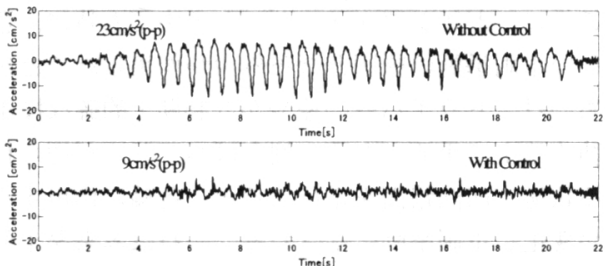

Fig5.2 Experimental results

\section{6. 結論}

以下に示す手段により, 消費電力の非常に小さな高 速エレベーター用アクティブ制振装置を開発すること ができた.

・ かご特性と外乱特性を考慮に入れた定性的な評価 により, 制御力最小化の観点から最適なアクチュ エー夕配置を決定した.

- 単位電力量に対する発生力が最大となるアクチュ エー夕方式を一定の寸法制約の下で最適設計する 手法を示し, 高効率な VCM 式アクチュエー夕を 開発した.

・ 低周波の加速度センサドリフトノイズに起因する 無䭾な消費電力を防止するデジタルフィル夕処理 技術を開発した。
また，かご振動低減性能と必要消費電力の少なさを 実機試験により確認した。

\section{文献}

(1) Yamazaki, Y. et al., Vibration Control of Super-High-Speed Elevators, Transactions of the Japan Society of Mechanical Engineers, Series C, Vol.60, No.579(1994), pp.3776-3781. (2) Okada, K. et al, Vibration Control of Super-High-Speed Elevators, Transactions of the Japan Society of Mechanical Engineers, Series C, Vol.60, No.579 (1994), pp.3782-3788.

(3) Yamazaki, Y. et al., Vibration Control of Super-High-Speed Elevators, Transactions of the Japan Society of Mechanical Engineers, Series C, Vol.61, No.581 (1995), pp15-21.

(4) Mutoh, N. et al., Horizontal Vibration Suppression Method Suitable for Super-High-Speed Elevators, Transactions of the Institute of Electrical Engineers of Japan, Series D, Vol.118, No.3, (1998), pp.353-362.

(5) Teshima, N. et al., Vibration Control of Ultra High Speed Elevator by Active Mass Damper, Transactions of the Japan Society of Mechanical Engineers, Series C, Vol.65, No.637, (1999), pp.3479-3485.

(6) Teshima, N. et al., Vibration Control of Ultra High Speed Elevator by Active Mass Damper, Transactions of the Japan Society of Mechanical Engineers, Series C, Vol.66, No.647, (2000), pp.2181-2186.

(7) Hirai, M. et al., Improvement of Control Stability of Active Mass Damper used in Super High Speed Elevator, Proceedings of the 7th Motion and Vibration Control Conference, No.01-6 (2001-4), pp.200-203.

(8) Saeki, J. et al., Vibration Control for High-Speed Elevator using Active Mass Damper, Proceedings of the 10th Transportation and Logistics Conference, No.01-36 (2001-12), pp.305-308.

(9) Itoh, S. et al., Vibration Control for High-Speed Elevator using Active Mass Damper, Proceedings of the 12th Transportation and Logistics Conference, No.03-51 (2003-12), pp.151-154.

(10) Obinata, G. et al., Simultaneous Optimization of Structure / Control Systems, Proceedings of the 76th Fall Annual Meeting of the Japan Society of Mechanical Engineers, No.98-3 (199810), pp.270-271.

(11) Utsunomiya, K. et al., Lateral Vibration Simulator for High-speed Elevators, Proceedings of the Asia-Pacific Vibration Conference Vol.2, pp.632-635.

(12) Yamakawa, K. et al., Design and Application of the Magnetic Circuit using Permanent Magnets (in Japanese), (1979), p.46-81, Sogo Electronics Press. 